Portland State University

PDXScholar

$12-2011$

\title{
Gendered Arrests or Gendered Sentencing: Explaining the Narrowing of the Gender Gap in Imprisonment over Time: 1970-2008
}

Mark G. Harmon

Portland State University

Robert M. O'Brien

University of Oregon

Follow this and additional works at: https://pdxscholar.library.pdx.edu/ccj_fac

Part of the Criminology and Criminal Justice Commons

Let us know how access to this document benefits you.

\section{Citation Details}

Harmon, Mark G., and Robert M. O'Brien. "Gendered arrests or gendered sentencing: Explaining the narrowing of the gender gap in imprisonment over time: 1970-2008." Sociological Perspectives 54.4 (2011): 641-664.

This Article is brought to you for free and open access. It has been accepted for inclusion in Criminology and Criminal Justice Faculty Publications and Presentations by an authorized administrator of PDXScholar. Please contact us if we can make this document more accessible: pdxscholar@pdx.edu. 


\title{
GENDERED ARRESTS OR GENDERED SENTENCING: EXPLAINING THE NARROWING OF THE GENDER GAP IN IMPRISONMENT OVER TIME: 1970-2008
}

\author{
MARK G. HARMON \\ Illinois State University \\ ROBERT M. O'BRIEN \\ University of Oregon
}

\begin{abstract}
Since 1970 the percentage of women incarcerated in U.S. prisons has risen from nearly 3 percent to almost 7 percent-more than doubling in less than 40 years. This article examines explanations for this phenomenon-concentrating on two: changes in the relative rates of arrest for females and males and sentencing reforms that were instituted during this period. The authors examine trends in female to male imprisonment rates from 1970 to 2008 across all fifty states using panel analysis. The only robust relationship they find is between the ratio of female to male incarceration rates and the ratio of female to male arrest rates for drug crimes. Sentencing reforms designed to limit the discretion of judges and those designed to limit the discretion of parole boards (the elimination of parole boards or truth in sentencing) are not related to changes in the ratio of female to male incarceration rates.

Keywords: imprisonment; women and crime; sentencing reforms
\end{abstract}

\section{INTRODUCTION}

An "imprisonment epidemic" occurred in the United States beginning in the 1970s. At the start of the 1970s the rates of incarceration per 100,000 U.S. residents hovered at slightly below 100 inmates per 100,000 U.S residents, but by 1980 had moved upward to 139 per 100,000. This upward movement increased to 297 in 1990 and by 2007 stood at 506 per 100,000. This amounted to a five-fold increase in the rate of incarceration over a 40-year period (Blumstein and Beck 1999; Pastore and Maguire 2007).

The increased rates of imprisonment involved both men and women. The rate for men rose from 191 per 100,000 men in the 1970 to 955 per 100,000 by 2007. The rate for women rose from 5 per 100,000 in 1970 to 69 per 100,000 by 2007. Despite

Address correspondence to: Mark G. Harmon, Campus Box 5250, Normal, IL 61761; e-mail: Mark.Harmon@ilstu.edu.

Sociological Perspectives, Vol. 54, Issue 4, pp. 641-664, ISSN 0731-1214, electronic ISSN 1533-8673.

(c) 2011 by Pacific Sociological Association. All rights reserved. Please direct all requests for permission to photocopy or reproduce article content through the University of California Press's Rights and Permissions website, at http://www.ucpressjournals.com/reprintinfo.asp. DOI: 10.1525/sop.2011.54.4.641. 
the higher rise for women, throughout this period, men continued to constitute well over 90 percent of those imprisoned. These increases are plotted in Figure 1 for both men and women (rates for men are represented by the triangles and rates for women by the squares and these rates correspond to the rates per 100,000 on the left-hand axis; Pastore and Maguire 2007).

Over this period the percentage of those imprisoned who were women rose markedly (represented by the stars on the stippled line in Figure 1 and corresponding to the percentages on the right-hand axis). In 1970 women constituted 2.87 percent of those incarcerated, but by 1980 this percentage had risen to 3.90 percent. By 1990 the percentage of those incarcerated who were women had grown to 5.48 percent and by 2007 it stood at 6.88 percent. This represents a more than doubling of the percentage of prisoners who were women from 1970 to 2007 (Pastore and Maguire 2007).

Although the upward trend in overall incarceration rates has been the focus of much literature in both scholarly outlets (Garland 2001; LaFree 1984; Zimring 2001) and in the popular press, much less attention has been paid to female-male compositional trends in U.S. prison populations (Kruttschnitt and Gartner 2003). Our interest focuses on this compositional trend that extends over the period from 1970 through 2008. Specifically, we focus our investigation on two potential explanations for part of this increase: the sentencing reform movements that occurred from the 1970s through the beginning of the $21^{\text {st }}$ century and changes in the ratio of female to male arrests for serious crimes. The analysis simultaneously assesses the effects of these two explanations, while controlling for other state-level variables, on the narrowing of the imprisonment gender gap.

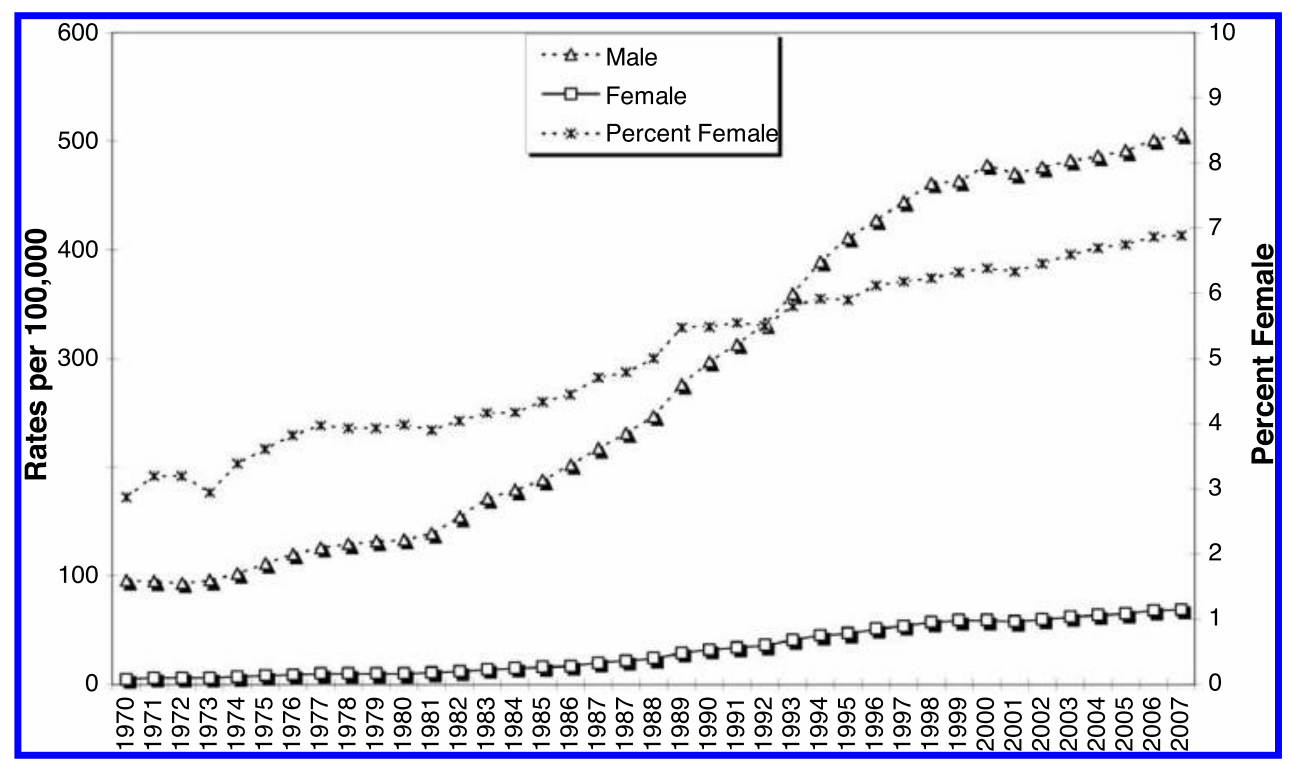

FIGURE 1

Imprisonment Rates for Males and Females and the Percentage of Those Incarcerated Who Are Females: 1970 to 2007 


\section{Arrest Effects on Imprisonment}

There are a number of potential explanations for the increase in the proportion of women prisoners. Two traditional explanations involve changes in the behavior (e.g., criminal behavior) of women and changes in the attitudes towards, and treatment of, women involved in criminal activities (O'Brien 2001). Both explanations could account for a narrowing of the gender gap in imprisonment (Adler 1975; Simon 1975; Sutherland 1947). They can draw their theoretical foundation from changes in treatment and/or changes in behavior. For example, a narrowing of the arrest ratio of females to males could result from either (or both) females committing more crimes (or male committing less) or women being treated as more culpable for crimes they have traditionally committed (Fox, Levin, and Quinet 2008; Schwartz, Steffensmeier, and Feldmeyer 2009). Related to these broader explanations are two more specific factors: changes in arrests and changes in sentencing policy.

Research has shown a narrowing of the gap in female to male arrest rates for various crimes. Steffensmeier, Schwartz, Zhong, and Ackerman (2005) and Chesney-Lind (1997), for example, found that women are arrested at increasing higher rates for violent crimes like assault. Notably, the rise in arrests occurs in spite of evidence that has shown that women are not actually committing substantially more assaults (Schwartz, Steffensmeier, and Feldmeyer 2009). General trends in Uniform Crime Report (UCR) statistics reported by the Federal Bureau of Investigation indicate that from the late 1970s to today women account for increasingly higher percentages of arrests: from about 10 percent of all index crimes in 1965 (homicide, rape, robbery, aggravated assault, burglary, larceny, and motor vehicle theft) to about one on five cases in 2008 (U.S. Department of Justice 1965-2008).

Research consistently shows an increase in arrests for females, but the cause of the rise is less clear. Some researchers argue that the narrowing of the arrest gap is due to increases and/or changes in criminal activity (Koons-Witt and Schram 2003). Such theories have been referred to as offender-generated or normative explanations (O'Brien 2003; Schwartz and Rookey 2008; Schwartz et al. 2009). These theories tend to view law enforcement and social policy as a reaction to changes in criminal behavior (D'Alessio and Stolzenberg 1995). Research analyzing actual criminal behavior among women has not tended to support the theory. While UCR data show a clear trend in increased arrests, victimization data and research into criminal behavior do not clearly indicate that the rise in arrests was preceded by a rise in criminal activity among women, at least not a rise as steep as the rise in arrests (Steffensmeier, Schwartz, Zhong, and Ackerman 2005).

It is possible that offender-generated explanations apply better to non-violent or less violent crime. For example, Steffensmeier et al. (2005) found that there has been some increase in criminal activity among women relative to men, but that these crimes have largely been limited to alcohol-related and minor violent felonies. Schwartz and Rookey (2008) suggest the increases among more minor crimes are most likely the result of changes in the application of the law and/or changes in the definition of the crimes being committed. As a result, what may appear to be more criminal activity is actually a phenomenon many criminologists call net-widening. 
Schwartz and Rookey (2008) describe a very clear example of net-widening due to changes in the law and how it affected the gender composition of those involved in the criminal justice system. They report that in many states the Blood Alcohol Content that defined the level of legal impairment was reduced from ".10 percent to .08 percent, or even to .02 percent for those under 21 years of age," and they note that "[p]olicies that redefine the legal criteria used to determine driver intoxication may inadvertently increase women's representation in official statistics, without any underlying change in women's actual drunk-driving behavior" (Schwartz and Rookey 2008:646). In this case, and in several others in the area of criminal justice, women are likely to commit less serious offenses. Thus, if one widens the net to include more minor forms of deviant behavior, one is likely to catch a relatively larger proportion of women and in the process decrease the gender gap. They provide a number of pieces of evidence to show that this is the case for driving under the influence.

In the same vein, other researchers point out that the narrowing of the gender gap in arrests could easily be explained as recording-generated changes ( $\mathrm{O}^{\prime}$ Brien 2003) or what Schwartz et al. (2009) refers to as changes in the law-in-action. The changes in arrests may be the result of police enforcement, changes in reporting practices, and/or changes in tolerance of behavior. To the extent recordinggenerated changes differentially affect males and females, they should affect the gender composition of those arrested and that could lead to changes in the composition of those incarcerated.

Specifically the literature suggests that shifts in U.S. drug policy, "e.g., the war on drugs," has been a major influence on the increase in prison populations (Blumstein, Cohen, Martin, and Tonry 1983; Payon 2006) and that women are increasingly being arrested and sentenced to prison for drug crimes (Gaskins 2004; Greenfeld and Snell 1999; Merlo and Pollock 2006). This war on drugs escalated shortly after the term was coined by Richard Nixon in 1969 (Inciardi, McBride, and Rivers 1996; Payon 2006). Nixon's drug wars were implemented as part of the Comprehensive Drug Abuse Prevention and Control Act of 1970 and have continued under different administrations during the period covered in this article. Although much has been written about the connection between the differential impact of the war on drugs and the imprisonment of blacks and whites (especially with respect to differential sentencing for crack and powder cocaine), much less research has examined the differential impacts on women and men.

The potential impact of changes in drug policies as a determinate of arrests among women and subsequently increases in their imprisonment is particularly plausible. In the United States the hegemonic gender normative view has tended to see women as mothers and the primary caregivers of children. This normative view may have interacted with the increased criminalization of drugs, which had a particularly strong effect on women. To illustrate, as drugs rose to one of the prime societal dangers women were viewed as more culpable as their drug use not only affects them personally but also affects their family, which society views as their primary responsibility (Belknap 2002; Chesney-Lind 1997; Owen 2000).

It is important to determine how much of the convergence in imprisonment rates is due to changes in offender-generated behavior and how much is due to 
changes in law-in-action, but this study cannot answer those questions. We can, however, determine if sentencing reforms and/or changes in arrest rates are associated with convergence in imprisonment rates, and (as noted above) there are several reasons for believing that they might be.

\section{Sentencing Reform Effects}

At the same time that women's arrest rates were rising, a shift in our criminal justice policy and focus occurred: the "get tough on crime" movement. ${ }^{1}$ The origins of the movement are often linked to the decade of the 1960s and increasing urban unrest that resulted in riots, radical youth and black power movements, assassinations of top political figures, and increasing crime rates (Beckett 1997; LaFree 1998; O'Brien 2003). These factors interacted with and were enhanced by media coverage (Scheingold 1991), public concerns (Warr 1995), and the political responses to these problems. In a sense, these interactions created a perfect storm that fostered the law and order movement. In response, the federal government formed the President's Commission on Law Enforcement and the Administration of Justice in 1969 and passed legislation establishing the Law Enforcement Assistance Administration - the LEAA - (part of the Omnibus Crime Control and Safe Streets Act of 1968). The LEAA supplied funds to law enforcement agencies to professionalize their operations and improve their record keeping.

The growing concern with crime as a social problem helped to generate concerns about the effectiveness of the criminal justice system in general. Issues such as the amount of discretion at all levels of law enforcement, concerns that some offenders were not receiving stiff enough sentences or being released too soon, and general issues of fairness for victims and offenders in the criminal justice system took on a new salience. These issues contributed to the calls to reform sentencing structures.

Until the 1970s judges retained much discretion in the sentencing of convicted offenders and parole boards were accorded considerable leeway in the determination of the release of offenders. There were, of course, maximum sentences for most crimes, but often there were no minimum sentences and in almost all cases there was a relatively wide range of sentences that could be imposed by judges. Parole boards, acting independently of judges, also had limits on their discretion in terms of paroling prisoners, but these limits were often wide and typically their decisions could not be appealed. This model of sentencing reflected the rehabilitation model of justice, where the focus centered on rehabilitating offenders within prisons through work and educational programs (Blumstein et al. 1983).

Blumstein et al. (1983) suggest several reasons for the sentencing reform movement, including prison uprisings (raising questions about rehabilitation), concern about individual rights and the control of discretion, demand for accountability, disillusionment with rehabilitation, disparity and discrimination in sentencing and parole, and crime control. As they note, "these factors, among others, coalesced into a compelling case against indeterminate sentencing. The indeterminate sentencing system that was all but universally supported in the 1950s had few defenders by the late 1970s" (Blumstein et al. 1983:3). 
The shift away from indeterminate sentencing represented a movement toward a "justice model" of crime and punishment that was in line with the get tough on crime movement that focused on making criminals pay and deterring those who might commit future crime. In a sense, the movement took to heart the three tenets of deterrence theory: to be effective punishment must be swift, certain, and severe. In terms of policy change they were most successful in instituting the latter two tenets. The demand was for the punishment to fit the crime (be certain) and be severe enough (at least more severe than before the reforms) to deter crime and/ or at least incapacitate the offender. The legal emphasis on "due process" makes it difficult to increase the swiftness of punishment. By the mid-1970s the sentencing reform movement began to have concrete effects on legislation with the adoption of several sentencing reforms (Bohm 2006; Garland 2001; Tonry 1995).

The uniformity and reduction in discretion created by sentencing reforms may have contributed to increasing the proportion of female prisoners. There are several possible explanations for such an effect. The first suggests that reforms may serve to widen the imprisonment net for offenders who have committed relatively minor crimes. For example, in 2006 men committed 76 percent of all UCR crimes, they committed 89 percent of homicides, 99 percent of all rapes, 89 percent of all robberies, and 79 percent of all aggravated assaults, but they only committed 61 percent of forgeries, 47 percent of embezzlements, and 36 percent of all prostitution offenses. In general, as the crime categories become less severe, women's proportion of those crimes increases (U.S. Department of Justice 1965-2008). While much of the rhetoric surrounding reforms has focused on the most violent of crimes (e.g., homicide and rape), research has indicated that the crime categories most affected are less violent crimes (e.g., assaults, robbery), drug crimes, and repeat offender (regardless of crime committed) (Frase 2005; Marvell 1995; Tonry 1995). To the extent that sentencing reforms served to increase sentences for less severe crimes more than more severe violent crime, it is possible that women will be affected more by reforms (Chesney-Lind 1997).

A second way in which reforms may increase female imprisonment is by changing the treatment of women by officials or, more specifically, the limiting of the ability of officials to be lenient. Historically, images of women have been marked by stereotypes. Women were viewed as pawns of biology, passive and weak, impulsive and nonanalytic, and impressionable (Shelden 2008). These stereotypes served to create a view of female criminals as less culpable than their male counterparts. Darrow (1922) predicted that as women's roles changed they would increasingly be judged as men are judged. That is, changes in attitudes toward women offenders means that they will be less likely to be treated differently in terms of culpability or to receive "chivalrous" treatment (Spohn 1999; Visher 1983). Sentencing reforms may enhance this change by increasing the bureaucratization in sentencing that emphasizes treating (ideally) all people the same (Savelsberg 1992), especially for repeat offenders where women may be most apt to lose their "chivalrous advantage." While some research (e.g., Koons-Witt 2002) indicates that reforms are not related to reductions in chivalrous actions, Griffin and Wooldredge (2006) found a specific reduction in shorter sentences for women with children after Ohio instituted sentencing guidelines. 
A third reason why sentencing reforms may result in increased female imprisonment is focused on the role of parole boards and parole decisions. Sentencing reforms can be categorized as (1) reforms that focused on the front-end, those that occur at the initial sentencing of convicted offenders, or (2) reforms that occurred at the back-end, those that focus on how much of a sentence that a judge imposes must be served (when and if parole can be considered and who controls parole decisions) (Stemen, Rengifo, and Wilson 2006). Therefore, the reforms that focus on limiting discretionary parole decisions may increase female sentences by denying officials the opportunity to release female inmates. Even if officials within prisons viewed women as less culpable and in some ways victims of circumstances (Spohn 1999), under reforms that remove or limit discretionary parole release female inmates would be "punished" more by this shift in policy (Walker, Spohn, and DeLone 2004).

It is also possible reforms had little effect on the "chivalrous" discretion of justice officials. As much as reforms have attempted to limit discretion, discretion has not been completely removed from the system. Koons-Witt (2002) found that in Minnesota after the introduction of sentencing guidelines officials returned to substantive justice decisions that included gendered stereotypes that, for example, punished women with children less severely as a result of the view that they are the primary caregivers. Additionally, Schwartz, Steffensmeier, and Feldmeyer (2009) found that while a considerable narrowing of the gender gap occurred in violent crime, it did not carry over to imprisonment. Conversely, literature focusing on drug crimes has generally indicated a link between drug arrests for men and women and imprisonment (Merlo and Pollock 2006; Spohn 1999; Walker, Spohn, and DeLone 2004).

\section{Expected Outcomes}

Hypotheses Relating to the Ratio of Female to Male Arrestees. We expect that the greater the ratio of female to male arrests for violent crimes within states, the greater the odds of incarceration of females to males within states; the greater the ratio of female to male arrests for property crimes within states, the greater the odds of incarceration of females to males within states; and the greater the ratio of female to male arrest for drug crimes within states, the greater the odds of incarceration of females to males within states. Given the previous literature, we expect this relationship to be especially salient for drug crimes and to a lesser degree lessserious property crime arrests (Chesney-Lind 1997; DPA 2003; Spohn 1999). Given the findings by Schwartz et al. (2009), we are less confident that this relationship holds for violent crime arrests.

While there have been increases in the number of women arrested for crimes, especially drug crimes, we expect that sentencing reforms have also contributed to the increased ratio of women to men incarcerated in the United States. The primary reason being that sentencing reforms have the potential to widen the net of those sentenced to prison (McMahon 1990). When discussing the phenomenon of net-widening, Cohen (1985:44) states: “(1) there is an increase in the total number of deviants getting into the system in the first place and many of these are new 
deviants who would not have been processed previously (wider nets); (2) there is an increase in the overall intensity of intervention, with old and new deviants being subject to levels of intervention (including traditional institutionalization) which they might not have previously received (denser nets); and (3) new agencies and services are supplementing rather than replacing the original set of control mechanisms (different nets)." Other researchers have indicated that sentencing may not be a factor in the narrowing of the gender gap in imprisonment. Steffensmeier et al. (2005) found that the net widens most at the beginning stages (e.g., the arrest stage) of justice system processes rather than at later stages such as sentencing.

Reforms may affect women more than men, both in terms of increases in the number of women who are imprisoned and in terms of increases in the length of sentences (both of which would increase the rate of female imprisonment). Changes in the sentencing laws were designed to equalize sentences for similar crimes. To the extent that women in the past may, for a variety of reasons (including gendered stereotypes of their roles in society as the primary caregivers), have received lighter prison sentences or community sanctions, we would expect reforms to have caused an increase in the odds of female imprisonment. Similarly, where truth in sentencing laws were implemented, we expect women who might have been released early for "chivalrous" or hardship reasons to no longer be eligible for such forms of release. Additionally, to the extent that these reforms have led to harsher treatment for more minor crimes, there is good reason to expect that the reforms may have differentially impacted women whose criminal behaviors are likely to be less serious than men's (Jacobs 2003; Spohn 1999; Steffensmeier and Demuth 2000). While research has shown that the top five crimes committed by men and women are similar, women's criminal behavior within those top five crimes has traditionally been both less severe and their criminal behavior has been seen as less culpable (Bloom, Owens, and Covington 2004; Koons-Witt and Schram 2003; Merlo and Pollock 2006).

Hypotheses Relating to Sentencing Reform. Given the discussion above, we expect that sentencing reforms will lead to increases in the rates of incarceration of women relative to those of men. Specifically, we expect that the adoption of presumptive sentencing guidelines, voluntary sentencing guidelines, statutory presumptive sentencing on the front-end (through their changes in sentencing) and truth in sentencing, and determinant sentencing on the back-end (through their focus on parole boards) will be associated with an increase in the odds of female to male incarceration rates in states controlling for other relevant variables (Jacobs 2003). We also examine the effects of the adoption of three strikes legislation-but are not sure how it will affect the relative rates of incarceration of females and males. Some prior research has indicated that because of the relatively few criminals, outside of California and Georgia, to be sentenced under the law, it has had little actual substantive impact (Dickey and Hollenhorst 1999; Kovandzic, Sloan, and Vieraitis 2004).

\section{Analytic Strategy}

To test our two explanations for the narrowing of the gender gap in imprisonment, we need a method that will allow us to compare rates before and after 
sentencing reform has been instituted and that will take into account changes in the gender composition of arrests for serious crimes. Such comparisons should be made with other cases where sentencing reforms have not been instituted so that we can compare changes in rates for cases where reform occurred to changes in rates for cases where reform did not occur. (Ideally, there would be random assignment of states to reforms-but this is not an option.)

The best methods available for conducting such comparisons for a large number of cases over a period of time are methods designed to analyze cross-sectional time-series or what are labeled in the econometric literature as panel models (see Baltagi 1995; Wooldridge 2002). Since sentencing reforms have been enacted at the state level, we will use states as our units (cases) and we have obtained data on imprisonment rates for men and women separately from 1970 to 2008. This gives us 1950 state-years of data for our analysis.

We are not the first to recognize the advantages of using panel analysis to study the effects of sentencing reform. Nicholson-Crotty (2004); Spelman (2009); Stemen et al. (2006); and Zhang, Maxwell, and Vaughn (2009) have used this form of analysis to investigate the effects of sentencing reforms on total rates of imprisonment. But we know of no research, to date, that has used this technique to investigate the potential effects of sentencing reforms on the relative rates of female to male incarceration.

Since our focus is on the effects of female to male crime rates and sentencing reform changes on the odds ratio of females to males incarcerated, we use a fixed effects model that controls for all variables at the state level that are constant over time. We also control for a number of variables within states that vary over time and theoretically may be related to the ratio of female to male incarceration within states, including unemployment rates, poverty rates, population density, percent urban, percent black, percent Hispanic, Republican state senate power, Republican state assembly power, Republican governor, state revenues per capita, and state correctional spending per capita.

These controls allow for testing the conditional association of the key independent variables (sentencing reforms and the ratios of females to males arrested within states) with the gender composition of the incarcerated state populations over time. As a final control we used fixed effects for periods, which controls for the association of exogenous shocks (e.g., the passage of the Omnibus Crime Bill Legislation of 1994 or the national election of a Republican president or a Republican majority in the Senate) on state level passage of sentencing reforms or law enforcement in action and state-level incarceration rates. The analysis allows for the modeling of the fluctuations in the gender composition of incarceration rates within fifty states over time. The regression coefficients represent the average effects in the fluctuation of the independent variables on the dependent variable for the average state (Finkel 1995; Halaby 2004).

\section{Data}

Dependent Variable. Data on the number of women and men incarcerated in the fifty states for each year from 1970 to 2008 were obtained from the U.S. 
Department of Justice (1965-2008). ${ }^{2}$ We used Bureau of the Census (1965-2008) population estimates to convert the state incarceration figures for males and females into rates. ${ }^{3}$ To measure shifts in the relative size of the female to male population of those incarcerated, we divided ${ }^{4}$ the female imprisonment rate by the male imprisonment rate and then logged this ratio. Logging the ratio of female to male imprisonment rates ensures that our results are not dependent upon whether we take the ratio of male to female rates rather than female to male rates (the only difference would be to change the signs of the coefficients for the independent variables in our analyses).

Sentencing Reform Variables. These variables are probably the most difficult to measure as there is no commonly agreed upon delineation (and thus their measurement warrants an extended discussion). Our categorizations were drawn from several sources including the U.S. Department of Justice (1996), Frase (1995), Zhang et al. (2009), and a report by the Vera Institute (Stemen et al. 2006). While most research is in agreement on the general outlines of the reforms discussed in this article, there is no consensus on the exact classification of each state into particular sentencing reform categories. Thus, researchers may disagree about whether a particular reform should be classified as a "presumptive sentencing guideline" or as a "voluntary sentencing guideline" or as something in between with a different name (Frase 1995; Marvell 1995; Tonry 1995). All these reforms, however, represent a shift from the rehabilitation model of sentencing. Because of this heterogeneity within and between our categories of sentencing reform, we will group various sets of reforms to see if there is a relationship between the entire set of reforms and the odds of females to males incarcerated and subsets of these reforms as well as the reforms individually (see Harmon 2011 for a detailed description of the classification of these reforms). Table 1 indicates when (what year) and where (in what states) these sentencing reforms were introduced.

We have coded presumptive sentencing guidelines, voluntary sentencing guidelines, and statutory presumptive sentencing as mutually exclusive "front-end" reforms that do not coexist with each other or indeterminate sentencing at any given time. Two reforms are back-end reforms that eliminate or limit discretionary release (determinate sentencing and truth in sentencing). These reforms can operate in conjunction with any of the front-end reforms. The final reform, three strikes laws, is a sentencing enhancement law and can go with any of the reforms above. It should be noted that these reforms were often made at different times both across and within states. For example, Oregon adopted presumptive sentencing guidelines in 1989, abolished parole in 1989, and adopted truth in sentencing in 1995 (U.S. Department of Justice 1996; Zhang et al. 2009).

Three major types of front-end reforms are evaluated in our research. They include two types of sentencing guidelines. The first, presumptive sentencing guidelines, consist of a matrix of possible sentences with narrower sentencing ranges within an offense category than indeterminate sentencing. The matrix is defined by the offender's criminal history (prior offenses) and offense severity. It is generally assumed that judges will follow the matrix, since the legal status of the reforms dictate that they must be followed or the sentence can be appealed. It constitutes the most structured and rational of the front-end reforms. The second guidelines, voluntary sentencing 
TABLE 1

Distribution of Sentencing Types Across the United States as of 2008

\begin{tabular}{|c|c|c|c|c|c|c|}
\hline & $\begin{array}{l}\text { Presum. } \\
\text { Guide. }\end{array}$ & Vol Guide. & $\begin{array}{c}\text { Stat. } \\
\text { Presum. }\end{array}$ & Deter. Sent. & $\begin{array}{c}\text { Truth in } \\
\text { Sent. }\end{array}$ & Three Strikes \\
\hline Alabama & - & 2006 & - & - & - & - \\
\hline Alaska & - & - & 1980 & - & - & - \\
\hline Arizona & - & - & 1978 & 1994 & 1994 & - \\
\hline Arkansas & - & 1994 & - & - & - & 1995 \\
\hline California & - & - & 1976 & 1976 & 1994 & 1994 \\
\hline Colorado & - & - & 1979 & 79-85 & - & 1994 \\
\hline Connecticut & - & - & - & $81-90$ & 1995 & 1994 \\
\hline Delaware & - & 1987 & - & 1990 & 1990 & - \\
\hline Florida & 1994 & 1983-93 & - & 1983 & 1995 & 1995 \\
\hline Georgia & - & - & - & - & 1995 & 1995 \\
\hline Hawaii & - & - & - & - & - & - \\
\hline Idaho & - & - & - & - & - & - \\
\hline Illinois & - & - & - & 1978 & - & - \\
\hline Indiana & - & - & 1977 & 1977 & - & 1994 \\
\hline Iowa & - & - & - & - & 1996 & - \\
\hline Kansas & 1993 & - & - & - & 1993 & 1994 \\
\hline Kentucky & - & - & - & - & - & - \\
\hline Louisiana & - & 1987 & - & - & - & 1994 \\
\hline Maine & - & - & - & 1976 & 1995 & - \\
\hline Maryland & - & 1983 & - & - & - & 1994 \\
\hline Massachusetts & - & - & - & - & - & - \\
\hline Michigan & 1999 & 1984-98 & - & - & 1994 & - \\
\hline Minnesota & 1980 & - & - & 1982 & 1993 & - \\
\hline Mississippi & - & - & - & 1995 & 1995 & - \\
\hline Missouri & - & 1997 & - & - & 1994 & - \\
\hline Montana & - & - & - & - & - & 1995 \\
\hline Nebraska & - & - & - & - & - & - \\
\hline Nevada & - & - & - & - & - & 1995 \\
\hline New Hampshire & - & - & - & - & - & - \\
\hline New Jersey & - & - & 1977 & - & - & 1995 \\
\hline New Mexico & - & - & 1977 & 1977 & - & 1994 \\
\hline New York & - & - & - & - & 1995 & - \\
\hline North Carolina & 1995 & - & - & 1981 & 1994 & 1994 \\
\hline North Dakota & - & - & - & - & 1995 & 1995 \\
\hline Ohio & 1996 & - & - & 1996 & 1996 & - \\
\hline Oklahoma & - & - & - & - & - & - \\
\hline Oregon & 1989 & - & - & 1989 & 1995 & - \\
\hline Pennsylvania & 1982 & - & - & - & 1991 & 1995 \\
\hline Rhode Island & - & - & 1981 & - & - & - \\
\hline South Carolina & - & - & - & - & - & 1995 \\
\hline South Dakota & - & - & - & - & 1996 & - \\
\hline Tennessee & 1989 & - & - & - & 1995 & 1995 \\
\hline Texas & - & - & - & - & - & - \\
\hline Utah & - & 1985 & - & - & 1985 & 1995 \\
\hline Vermont & - & - & - & - & - & 1995 \\
\hline
\end{tabular}


TABLE 1

Distribution of Sentencing Types Across the United States as of 2008 (Continued)

\begin{tabular}{lcccccc}
\hline & $\begin{array}{c}\text { Presum. } \\
\text { Guide. }\end{array}$ & Vol Guide. & $\begin{array}{c}\text { Stat. } \\
\text { Presum. }\end{array}$ & Deter. Sent. & $\begin{array}{c}\text { Truth in } \\
\text { Sent. }\end{array}$ & Three Strikes \\
\hline Virginia & - & 1995 & - & 1995 & 1995 & 1994 \\
Washington & 1984 & - & - & 1984 & 1984 & 1993 \\
West Virginia & - & - & - & - & - & - \\
Wisconsin & - & $85-94,99$ & - & - & 1999 & 1994 \\
Wyoming & - & - & - & - & - & - \\
Total & 10 & 11 & 8 & 18 & 24 & 24 \\
\hline
\end{tabular}

Note: Table 1 represents the current sentencing type used by each state as of 2008. Presum. Guide. = presumptive sentencing guidelines; Vol. guide. $=$ voluntary sentencing guidelines; Stat. Presum. Sent. $=$ statutory presumptive sentencing; Deter. Sent. = determinate sentencing; Truth in sent. stands = truth in sentencing; Three strikes = three strikes laws. All other states utilize indeterminate sentencing.

guidelines, are not as enforceable as presumptive sentencing guidelines because they are not "legally binding," allowing the judge to deviate from the matrix without the possibility of appeal and thus serve as only a formal recommendation. The difference between the two types is one of legal mechanisms. States with presumptive sentencing guidelines have "legally binding" sentencing matrixes enforceable by appellate review, allowing both the prosecution and defense to appeal sentences not following the guidelines. In states with voluntary sentencing guidelines, there is no appellate review. While the judge may be required to give a written justification when deviating from the voluntary sentencing guidelines, he or she is not legally obligated to follow them (Frase 1995; Stemen et al. 2006; Zhang et al. 2009). Research indicates that judges follow the recommendations of voluntary guidelines 85 percent of the time, suggesting they do have an impact (Marvell 1995).

Statutory presumptive sentencing is the least structured of the three front-end sentencing reform categories assessed. Like sentencing guidelines, statutory presumptive sentencing represents an attempt to create uniformity in sentencing for similarly serious crimes-but acts less like a sentencing rubric. It specifies an "appropriate" or "normal" sentence for each offense as a guide for the judge. It can be considered along with other relevant factors (aggravating or mitigating circumstances), but its primary intent is to "fit the punishment to the crime" rather than "fit the punishment to the offender" (Brewer, Beckett, and Holt 1981; Frase 1995; Savelsberg 1992).

The back-end reforms make up a second set of reforms. Truth in sentencing concentrates on how much of a sentence made by a judge must be served. Truth in sentencing legislation was first passed in Washington in 1984 and twentyfour states now have such laws. These laws require that those convicted serve a statutorily defined minimum amount of time. ${ }^{5}$ The second major back-end reform now includes twelve states and involves the elimination of discretionary parole boards. We follow the tradition in the literature and label this reform determinant sentencing (Frase 1995; Stemen et al. 2006; Zhang et al. 2009).

The final sentencing reform that is considered involves an enhanced sentencing procedure called three strikes laws. Although California may be most famous for 
this law, there are twenty-four states with some form of a three strikes law. These laws focus on habitual offenders who are convicted of a third felony. Typically the law suggests severe sentences (e.g., 25 years to life or a life sentence) for the third felony offense (Frase 1995; Kovandzic, Sloan, and Vieraitis 2004; Lotke, Colburn, and Schiraldi 2004; Stemen et al. 2006; Zhang et al. 2009).

Traditionally dummy variable coding has been used to represent the period without the reform (coded with zeros) and after the reform is instituted (coded with ones). This assumes that the effect of these reforms on (in our case) the ratio of female to male imprisonment rates is instantaneous, even though most of those incarcerated were in prison before the legislation. The problem is that even after the reform takes effect, during the first few years the ratio of females to males incarcerated is in large part determined by the ratio before the reform took effect. Only after a few years is this ratio determined by those sentenced after the reform took effect. To ameliorate this problem, we created a new sentencing measure where each state was coded as 1.00 for the first year of implementation as well as for the years before implementation and as $e$ (2.71828) for Year 5 through the last year of observation. The intervening years between one and five ${ }^{6}$ were coded in an equal interval manner between 1.00 and 2.71828 (an increase of 42957 per year). We then calculated the natural log of these numbers to create a variable that was zero for the years before implementation, and for one year after implementation and then a logged growth curve during the first 5 years of implementation, and then a constant of one (the natural log of 2.71828) thereafter. Because we only focus on imprisonment data, which include only individuals sentenced to more than 1 year, a 1-year lag seems appropriate. The logarithmic growth from Year 1 to 5 seems more realistic than the instantaneous full effect in gender composition implied by the use of dummy variables to code sentencing reforms.

Crime Variables. The other key independent variables are more straightforward to code. We code the three variables representing the gender composition of arrests as the natural log of the ratio of female arrest rates to male arrest rates. Specifically, the three arrest ratios are based on arrest rates for females and males for violent crimes (murder, forcible rape, robbery, and aggravated assault), property crimes (burglary, larceny, and motor vehicle theft), and drug crimes (distribution and possession) over time. Data on the number of female and male arrestees were obtained from the FBI (U.S. Department of Justice 1965-2008), while population data for the states were obtained from the U.S. Census (1965-2008). These data allowed us to construct yearly arrest rates for females and males and their ratios.

Control Variables. In order to determine whether the sentencing reforms had an effect on the ratio of female to male incarceration rates in states (an average treatment effect), it is important to control for other variables within states that might have increased or decreased this ratio (especially those that might be correlated with our key independent variables). The Bureau of Labor Statistics (U.S. Department of Labor 1965-2008) supplied information to construct data on unemployment rates, while the U.S. Bureau of the Census (2006) provided data for poverty rates. Dubin (2007) supplied data on political party affiliation for state senate and house (or assembly) from which we constructed a Republican control index by centering the percent Republican around 50 percent so that Republican control 
represents positive deviations from 50 percent and Democratic control represents negative deviations. We then logged the absolute value of the deviations and returned the negative signs to the Democratic deviations and a zero to an evenly split body. This made the transition from Democratic to Republican control be the most important part of the scale. A dummy coded variable for governor's political party was generated from data supplied by Hershey (2007). Finally, we controlled for state revenues per capita and state correctional spending per capita (Stemen 2007). These control variables represent variables that have been shown to affect prison populations in past research (DeFina and Arvanites 2002; Engen and Gainey 2000; Steffensmeier and Demuth 2000; Tonry 1994; Walker et al. 2004; Western 2005).

\section{RESULTS}

We used STATA's xtreg program ${ }^{7}$ (StataCorp 2009) in our analyses because it allows us to estimate panel models for random or fixed effects and to consistently estimate the standard errors of our coefficients even with serial correlation within panels and heteroscedasticity between panels by using the cluster option. In our analyses we use fixed effects for units (states) to control for all characteristics associated with states that do not vary over time. This is crucial because our analysis focuses on changes in the gender composition within states over time. ${ }^{8}$ In addition, the Hausman test ${ }^{9}$ indicates that we should use fixed effects for states because we violated the statistical assumptions of the random effects model. We also include dummy variables for periods, because the $F$ test indicates significant variation over time in the predicted values of the dependent variable across periods (indicated by the $F$ values in the last row of Table 2) and because the Hausman test indicates that we need to include the fixed effects for periods. ${ }^{10}$

Table 2 contains the results of our analyses. We begin with a baseline model that contains the log of the ratio of female to male arrest rates for violent crimes, the $\log$ of female to male arrest rates for property crimes, and the log of female to male arrest rates for drug crimes. Each of these has been suggested as a potential reason for the increasing incarceration rates of females relative to males. Perhaps somewhat surprisingly, only the logged ratio of female to male arrest rates for the drug crimes is significantly related to the logged ratio of female to male incarceration rates for these fifty states across the period 1970 to 2008. Since both the dependent and independent variables are logged, we can interpret the coefficient associated with the gender composition of drug crime arrests as indicating that a 1 percent change in this ratio is associated with a .341 percent change in the ratio of female to male incarceration rates.

Model 2 adds the sentencing reform variables. None of them is significantly associated with the gender composition of prisoners at the .05 level, but the adoption of truth-in-sentencing laws is marginally significant at the .10 level for a twotailed test. We note that this coefficient is negative (not the hypothesized direction). Controlling for these sentencing reforms changes the relationships for the arrest ratio variables in Model 1 only slightly. Only the ratio of female to male drug crime arrestees is statistically significant (here at the .01 level) and its relationship is only slightly less strong than in Model 1: a 1 percent change in this variable is 
TABLE 2

Changes in the Log Odds of Female to Male Imprisonment over Time: 1970-2008

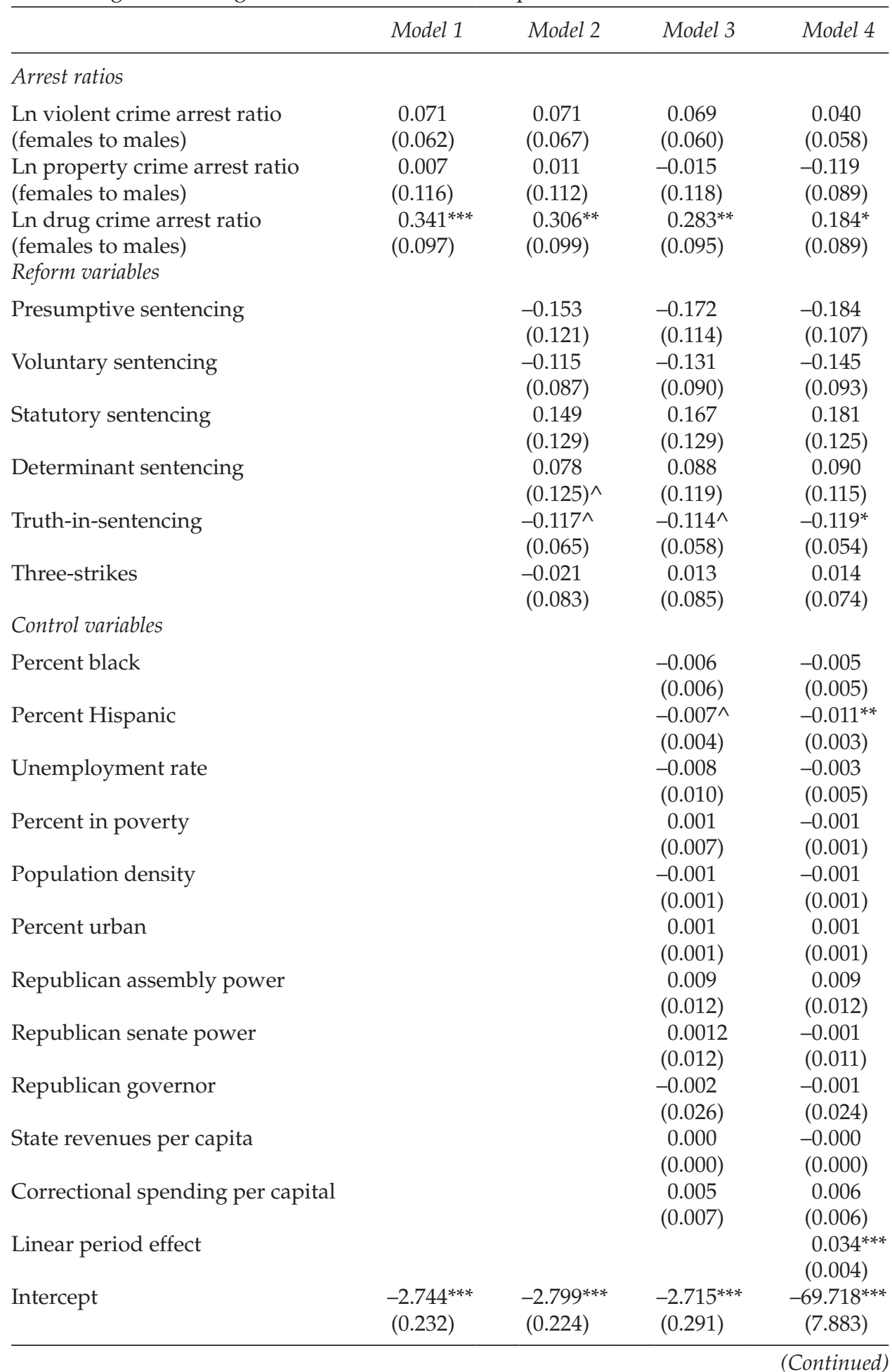


TABLE 2

Changes in the Log Odds of Female to Male Imprisonment over

Time: 1970-2008 (Continued)

\begin{tabular}{lllll}
\hline & Model 1 & Model 2 & Model 3 & Model 4 \\
\hline$N$ & 1,880 & 1,880 & 1,880 & 1,880 \\
$F(38,49)$ & $46.10^{* * *}$ & $50.83^{\text {*** }}$ & $29.28^{\text {**** }}$ & \\
\hline
\end{tabular}

Note: Standard errors in parentheses.

$\wedge p<0.10,{ }^{*} p<0.05,{ }^{* *} p<0.001,{ }^{* * *} p<0.001$.

associated with a .306 percent change in the gender composition of the incarcerated population.

Model 3 adds a long list of control variables that have been found to be associated with imprisonment in past studies and all of them are measured for each state yearly from 1970 to 2008: percent black, percent Hispanic, unemployment rate, percent living below the poverty level, population density, percent urban, Republican control of the assembly/house, Republican control of the senate, Republican governor, state revenues per capita, and correctional spending per capita. None of these variables are significantly related to the gender composition of those incarcerated in the states, although percent Hispanic is significant at the .10 level and negatively related to the ratio of females to males incarcerated. Again truthin-sentencing is marginally significant at the .10 level and its coefficient is nearly identical to Model 2. The logged ratio of female to male drug arrests remains the only statistically significant variable in predicting the logged ratio of rates of females to males incarcerated at the state level.

We tried several other auxiliary analyses. We interacted each of the front-end sentencing reform variables (presumptive sentencing, voluntary sentencing, and statutory sentencing) with each type of back-end reform (determinate sentencing and truth-in-sentencing) - for a total of six interaction terms. None of these interactions were even marginally statistically significant. We use an F-test to see if the front-end, back-end, or all of the reform variables together were statistically significant and found that they were not. For the time period covered in this analysis, we find only one of the variables that we examined to be significantly related to the gender composition of those incarcerated: the gender composition of those arrested for drug crimes. None of the sentencing reform variables has a statistically significant relationship with the gender composition of those incarcerated over this period.

Some authors (Beck and Katz 1995; Halaby 2004; Wooldridge 1995) worry about controlling for differences between periods using dummy variables for each period (with the exception of the reference period). We know from the $F$ test at the bottom of Table 2 that in each of our models the thirty-eight dummy variables for periods account for a statistically significant amount of variability in the dependent variable controlling for all of the other independent variables in each model. We also know from Hausman tests that fixed effects for time should be used rather than using no control for time trends. Model 4 represents a more modest approach to modeling the trends across periods: it contains a linear trend for periods. We 
decided on this modeling of period variation because when we added quadratic and cubic period effects, they did not significantly improve the fit of the model (they were not statistically significant). Finally, when we use a Hausman test to compare Model 3 to Model 4, we find that Model 4 is appropriate in terms of providing consistent estimates. While we might still prefer the model with dummy variables for periods (Model 3) because of its rigorous controls, Model 4 may be more appropriate because it does not "wash out" as much variation and is likely more efficient. When we interpret the results from Model 4, we still find that the effects of drug crimes (ratio of female to male) were significant, but now the effects of truth-in-sentencing and percent Hispanic are both statistically significant. And, of course, the linear effect of period is positive and statistically significant at the .001 level in this no period dummy variables model. Each increase of 1 year in time is associated with a 3.458 percent increase in the ratio of females to males incarcerated-the annual rate of increase $[3.458=(\exp (0.034)-1) \times 100]$.

\section{DISCUSSION}

Net-widening, for us, involves an increase in the proportion of people who are caught up in the criminal justice system. It is often accompanied by a shift in the demographic composition of the people caught up in that system. In terms of arrest rates, there was a trend upward for violent crimes from 1970 to the early 1990s with a substantial drop after that date. For property arrest rates, there was an increase from 1970 to the early 1980s followed by a period of fluctuating rates with a definite downturn after the early 1990s. There is a large literature on changes in the gender gap for serious violent and property crimes over this period (Bloom et al. 2004; Bloom, Owens, Rosenbaum, and Deschenes 2003; Chesney-Lind 1997; Gaskins 2004; Merlo and Pollock 2006; O'Brien 1999; Schwartz et al. 2009; Steffensmeier 1980; 1993). Overall the literature suggests a slight narrowing of the arrest rates gap between males and females for some of these crimes.

Drug crime arrests have increased for both males and females over the period covered by this study, but have been growing at a significantly higher rate for women. America's 25-year war on drugs has had a massive impact on the criminal justice system. Drug arrests have tripled since 1980; as a result, the number of all inmates imprisoned for drug offenses in 2000 equals the total number of all inmates in U.S. prisons and jails in 1975. Research has shown that the rates of women going to prison due to drug offenses have increased more rapidly than for men (Bloom et al. 2004; DPA 2003; Greenfeld and Snell 1999; Merlo and Pollock 2006). Though men still represent the majority of drug arrests, women now make up the fastest growing sub-group of the population going to prison because of drug crimes. The percentage of female inmates convicted of drug crimes has risen from around 11 percent in 1979 to about 32 percent in 2002, while the percentage of males in prison convicted of drug crimes was about 21 percent (U.S. Department of Justice 1965-2008). By the mid-1990s the proportion of women in prison for drug crimes was almost double that of men (Greenfeld and Snell 1999).

In our analyses, we find that the gender composition of those arrested for serious violent crimes and property crimes in states is not significantly associated 
with the gender composition of those incarcerated, but the gender composition of those arrested for drug crimes is associated. The effect is strong and consistent across all of the models used in our analysis, including Models 3 and 4, which should provide consistent estimates in the face of both unit and period time invariant variables. This finding reinforces the perspective that the war on drugs is in part a war (even if unintentionally) on women (Belknap 2002; Owen 2000). Of note is research that has shown that the war on drugs was also racialized and affected blacks and Hispanics more than whites. It is likely that the rise in female imprisonment has not been the same across racial/ethnic groups; in fact, research has shown that black women's imprisonment rates are the single fastest growing group (Griffin and Wooldredge 2006; Owen 2000; Steffensmeier 1993). With black women more likely to be involved in drug crime arrests (Spohn, Welch, and Gruhl 1985), future research should focus on testing the possible connection between the war on drugs and the very rapid increase in the imprisonment of women of color.

We did not find, however, that the sentencing reforms (as examined in this article) are associated with the ratio of female to male incarceration rates in states over this time period. This finding contradicts our own expectations and those of others. For example, Jacobs (2003:3) states that the increase in women's imprisonment "corresponds directly to the mandatory minimum sentencing laws in effect since the early 1970s. Since more women are convicted on non-violent, drug related crimes than for any other, these sentencing policies have had a particularly profound effect on women." We do not find this effect once we control for the ratio of females to males arrested for drug-related crimes. Our dependent variable, however, does not assess directly the ratio of female to male incarcerations for drug crimes. If it did, it is possible that we would find that the sentencing reforms are related to differences in this ratio. We also have coded our key independent variables on sentencing reforms in the traditional manner and not with an eye towards their treatment of drug offenses. Such a coding of reforms might find that reforms specifically and harshly targeting drug crimes were related to the ratio of female to male incarcerations. Such an investigation is a topic for future research, as well as a careful examination of distribution of drug crimes for males and females (e.g., manufacture, distribution, and use).

Our data are consistent with the effects of the law and order movement on the gender gap occurring earlier in the process than the sentencing reforms (e.g., during arrests or choice of prosecutions), since the effects of reforms were absent after controlling for the ratio of female to male arrests. This suggests that sentencing is just passing along the narrowing of the gender gap present earlier in the chain of custody (Steffensmeier et al. 2005).

Net-widening has certainly occurred in the area of incarceration and that increase is graphically portrayed in Figure 1; also portrayed is the differential increase of the proportion of women incarcerated over time that has accompanied this increase. To the extent that sentencing reforms have contributed to netwidening, we might expect that they have contributed to the narrowing of the gender gap in incarceration (Greenfeld and Snell 1999). Notably, prior research has cited sentencing reforms as a possible explanation for the increase in imprisonment for women (Steffensmeier and Demuth 2000). An important finding of this research is that we find no evidence of this for any of the front-end reforms, the back-end reforms, or three strikes laws at the state level. This held true even when 
we examined combinations of these front-end and back-end reforms. This research does provide evidence that the gender composition of drug arrests has contributed to a narrowing of the gender gap in incarcerations even when taking into account changes in sentencing policy. We believe that this shift in the gender composition of drug arrests is due to net-widening associated with the war on drugs.

Acknowledgments: This investigation is based upon work supported by the National Science Foundation under Grant No. SES-0921906 and The Center on Diversity and Community and The Center for the Study of Women in Society at the University of Oregon.

\section{NOTES}

1. In this article the "get tough on crime" movement and the law and order movement are treated synonymously and refer to the same general period and movement aimed at increasing the punitive nature of the criminal justice system in response to a perceived rise in criminal activity.

2. Data for the years 1970 to 1983 are available in the yearly publication produced and printed by the U.S. Department of Justice (1965-1983) "Bureau of Justice Statistics, Prisoners in State and Federal Institutions on December 31, 1965 (through 1983)". Data for the years 1984 to 1998 are available in the yearly publication "Bureau of Justice Statistics, Correctional Populations in the United States, 1984 (throught 1998)" (U.S. Department of Justice1984-1998). Data for the years 1999 to 2005 are available in the yearly publication "Bureau of Justice Statistics, Prisoners, 1999 (through 2008)" (U.S. Department of Justice. 1999-2008).

3. Rates per 100,000 for each variable were computed by taking the raw number of prisoners for each state by year that was provided by the Bureau of Justice Statistics and dividing by each state's female or male population per 100,000, respectively, as supplied by the Bureau of the Census.

4. Dividing the two rates creates an odds ratio that measures the odds of female imprisonment per 100,000 to male imprisonment per 100,000.

5. In our coding of this variable we included only states meeting the 1994 federal omnibus crime bill minimum 85 percent time served of the original sentence.

6. Year 5 was chosen as the last year of the logged increase because the average (medium) offender is sentenced to a little less than 2.5 years. Very few offenders actually serve a sentence longer than 5 years, making Year 5 seem an appropriate stopping point of the logarithmic growth curve.

7. We first tested our panel data to see if they contained a unit root. This is accomplished by running a unit root test on the dependent variable across all of the fifty panels of state data. If the panels contain a unit root, this suggests that the data should be first differenced. A unit root occurs when a random shock at one period is perfectly transmitted to the next period ("perfect memory") and is particularly likely to occur when the dependent variable is based on a "stock" rather than a "flow." In our case the proportion of females to males imprisoned in a given year is largely based on the composition of the stock of prisoners the year before with a smaller flow component based on those who leave prison and those who enter prison. We used both the Dickey-Fuller and PhillipsPerron tests as modified for STATA (StataCorp 2009), which uses a Fisher-based metaanalysis that combines $p$ values from the independent panels to obtain an overall statistic for testing the results over all fifty panels. Within the unit root test we used lags of two 
and three periods, which should be enough to model any autocorrelation that would remain after first differencing. As long as we demeaned the data as suggested by Levin, Lin, and Chu (2002) or included a drift or trend term (which is also appropriate), the tests rejected the null hypothesis that the panels contained unit roots at greater than the $p=.001$ level. Therefore, we did not first difference these panel data.

8. Fixed effects for panels exploit within-group variation by holding constant unexplained between-group variation. The fixed effects estimates are unbiased even if some timeinvariant state-level characteristics are correlated with other independent variables and the dependent variable. This is not the case in random effects models when these correlations are present. In our analyses the unit (state) fixed-effects model offers significant advantages over the random effects model (Halaby 2004).

9. The Hausman test can be used to assess the likelihood that a key assumption of the random effects model is correct: that no unobserved time-invariant state characteristics are correlated with the independent variables in the model and the dependent variable. If this assumption is not correct, then the coefficient estimates based on the random effects model will be biased. Our results, based on the Hausman test, indicate that using the random effects model would result in biased coefficients, and thus, we use the fixed effects model for states in all of our analyses (Baltagi 1995).

10. This Hausman test assesses whether period characteristics are correlated with the independent variables in the model and the dependent variable. If they are, not including fixed effects (dummy variables) for periods would result in biased coefficient estimates. This Hausman test compares the fixed effects for states model with the fixed effects for states and periods model (with both models including other time-varying independent variables); the test indicates that we should include fixed effects for periods.

\section{REFERENCES}

Adler, Freda. 1975. Sisters in Crime. New York: McGraw-Hill.

Baltagi, Badi. 1995. Econometric Analysis of Panel Data. New York: John Wiley \& Sons.

$\rightarrow$ Beck, Nathaniel and Jonathan N. Katz. 1995. "What to Do (and Not to Do) with Time-Series Cross-Section Data." American Political Science Review 89(3):634-47.

Beckett, Katherine. 1997. Making Crime Pay: Law and Order in Contemporary American Politics. New York: Oxford University Press.

Belknap, Joanne. 2002. The Invisible Woman: Gender, Crime and Justice. Belmont, CA: Wadsworth.

Bloom, Barbara, Barbara Owens, and Stephanie Covington. 2004. "Women Offenders and the Gendered Effects of Public Policy." Preview of Policy Research 21(1):31-48.

, Barbara Owens, Jill Rosenbaum, and Elizabeth Piper Deschenes. 2003. "Focusing on Girls and Young Women: A Gendered Perspective on Female Delinguency." Women and Criminal Justice 14(2/3):117-36.

Blumstein, Alfred and Allen J. Beck. 1999. "Population Growth in U.S. Prison Populations, 1980-1996." Pp. 17-61 in Crime and Justice: A Review of Research, volume 26, edited by M. H. Tonry and J. Petersilia. Chicago: University of Chicago Press.

_ J Jacqueline Cohen, Susan E. Martin, and Michael H. Tonry. 1983. "Research on Sentencing: The Search for Reform," Volume 1. Washington, D.C.: National Academy Press.

Bohm, Robert M. 2006. "'McJustice': In the McDonaldization of Criminal Justice." Justice Quarterly 23(1):127-46. 
Brewer, David, Gerald E. Beckett, and Norman Holt. 1981. "Determinate Sentencing in California the 1st Years Experience." Journal of Research in Crime and Delinquency 18:200-31.

Chesney-Lind, Meda. 1997. The Female Offender: Girls, Women and Crime. Thousand Oaks, CA: Sage.

Cohen, Stanley. 1985. Visions of Social Control: Crime, Punishment and Classification. Cambridge, UK: Polity.

D'Alessio, Stewart J. and Lisa Stolzenberg. 1995. "The Impact of Sentencing Guidelines on Jail Incarceration in Minnesota." Criminology 33(2):283-302.

Darrow, Clarence. 1922. Crime: Its Causes and Treatment. Montclair, NJ: Patterson-Smith.

DeFina, Robert. H. and Thomas. M. Arvanites. 2002. "The Weak Effect of Imprisonment on Crime: 1971-1998." Social Science Quarterly 83(3):635-53.

Dickey, Walter J. and Pam Hollenhorst. 1999. "Three-Strikes Laws: Five Years Later." Corrections Management Quarterly 3(3):1-18.

DPA. 2003. "Race and the Drug War." In Drug Policy Alliance. Available at http:/ / www.drugpolicy.org/race/womenoofcolor

Dubin, Michael J. 2007. Party Affiliations in the State Legislatures: A Year by Year Summary, 17962006. Jefferson, NC: McFarland.

Engen, Rodney L. and Randy R. Gainey. 2000. "Modeling the Effects of Legally Relevant and Extralegal Factors Under Sentencing Guidelines: The Rules Have Changed." Criminology 38(4):1207-29.

Finkel, Steven E. 1995. Causal Analysis with Panel Data. Thousand Oaks, CA: Sage Publications.

Fox, James Alan, Jack Levin, and Kenna Quinet. 2008. The Will to Kill: Making Sense of Senseless Murder. Boston: Pearson/Allyn.

Frase, Richard S. 1995. "State Sentencing Guidelines-Still Going Strong." Judicature 78(4):173-80.

$\rightarrow$ - 2005. "State Sentencing Guidelines: Diversity, Consensus, and Unresolved Policy Issues." Columbia Law Review 105(4):1190-232.

Garland, David. 2001. The Culture of Control: Crime and Social Order in Contemporary Society. Chicago: University of Chicago Press.

Gaskins, Shamica. 2004. "'Women of Circumstance'-The Effects of Mandatory Minimum Sentencing on Women Minimally Involved in Drug Crimes." American Criminal Law Review 41(4):1533-54.

Greenfeld, Lawrence A. and Tracy L. Snell. 1999. Women Offenders. Washington, DC: Bureau of Justice Statistics.

Griffin, Timothy and John Wooldredge. 2006. "Sex-Based Disparities in Felony Dispositions Before Versus After Sentencing Reform in Ohio." Criminology 44(4):893-923.

Halaby, Charles. 2004. "Panel Models in Sociological Research: Theory Into Practice." Annual Review of Sociology 30:507-44.

Harmon, Mark G. 2011. “The Imprisonment Race: Unintended Consequences of 'Fixed' Sentencing on People of Color over Time." Journal of Ethnicity in Criminal Justice 9(2):79-109.

Hershey, Marjorie Randon. 2007. Party Politics in America. New York: Pearson Longman.

Inciardi, James, Duane McBride, and James Rivers. 1996. Drug Controls and the Courts. Thousand Oaks, CA: Sage Publications.

Jacobs, Ann L. 2003. The Population of Women in Prison Increases Rapidly. New York, NY: Women's Prison Association.

Koons-Witt, Barbara A. 2002. "The Effect of Gender on the Decision to Incarcerate Before and After the Introduction of Sentencing Guidelines." Criminology 40(2):297-327. and Pamela J. Schram. 2003. "The Prevalence and Nature of Violent Offending by Females " Journal of Criminal Justice 31(4):361-71. 
Kovandzic, Tomislav V., John J. Sloan, and Lynne M. Vieraitis. 2004. "'Striking Out' as Crime Reduction Policy: The Impact of 'Three Strikes' Laws on Crime Rates in US Cities." Justice Quarterly 21(2):207-39.

Kruttschnitt, Candace and Rosemary Gartner. 2003. “Women's Imprisonment.” Pp. 55-135 in M. Tonry (ed.) Crime and Justice: A Review of Research, Vol. 30. Chicago: University of Chicago Press.

LaFree, Gary. 1984. "Adversarial and Non-Adversarial Justice: A Comparison of Guilty Pleas and Trials." Criminology 23(3):289-312. . 1998. Losing Legitimacy: Street Crime and the Decline of Social Institutions in America. Boulder, CO: Westview.

Levin, Andrew, Chien-Fu Lin, and Chia-Shang James Chu. 2002. “Unit Root Tests in Panel Data: Asymptotic and Finite-Sample Properties." Journal of Econometrics 108 (1):1-24.

Lotke, Eric, Jason Colburn, and Vincent Schiraldi. 2004. 3 Strikes \& You're Out: An Examination of the Impact of Strikes Laws 10 Years After Their Enactment. Washington, DC; Justice Policy Institute.

Marvell, Thomas B. 1995. "Sentencing Guidelines and Prison Population-Growth." Journal of Criminal Law \& Criminology 85(3):696-709.

McMahon, Maeve. 1990. "'Net-Widening' Vagaries in the Use of a Concept." The British Journal of Criminology 30(2):121-49.

Merlo, Alida V. and Joycelyn M. Pollock. 2006. Women, Law, and Social Control. Boston: Pearson/Allyn and Bacon.

$\rightarrow$ Nicholson-Crotty, S. 2004. "The Impact of Sentencing Guidelines on State-Level Sanctions: An Analysis Over Time." Crime \& Delinquency 50(3):395-411.

O'Brien, Robert M. 1999. "Measuring the Convergence/Divergence of 'Serious Crime' Arrest Rates for Males and Females: 1960-1995." Journal Quantitative Criminology 15(1):97-114.

$\rightarrow \longrightarrow$. 2001. "Theory, Operationalization, Identification, and the Interpretation of Different Differences in Time Series Models." Journal of Quantitative Criminology 17(4):359-75. . 2003. "UCR Violent Crime Rates, 1958-2000: Recorded and Offender-Generated Trends." Social Science Research 32(3):499-518.

Owen, Barbara. 2000. "Women and Imprisonment in the United States: The Gendered Consequences of the US Imprisonment Binge." Pp. 81-98 in Harsh Punishments: International Experiences of Women's Imprisonment, edited by S. Cook and S. Davies. Boston: Northeastern.

Pastore, Ann L. and Kathleen Maguire. 2007. "Sourcebook of Criminal Justice Statistics, Table 6.28.2007." Available at http:/ /www.albany.edu/sourcebook/.

Payon, Tony. 2006. The Three U.S.-Mexican Border Wars: Drugs Immigration and Homeland Security. Santa Barbara, CA: Praeger Security International.

StataCorp. 2009. Stata Statistical Software: Release 11. College Station, TX: StataCorp LP.

$\rightarrow$ Savelsberg, Joachim. 1992. "Law That Does Not Fit Society: Sentencing Guidelines as a Neoclassical Reaction to the Dilemmas of Substantivized Law." American Journal of Sociology 97(5):1346-81.

Scheingold, Stuart A. 1991. The Politics of Street Crime: Criminal Process and Cultural Obsession. Philadelphia: Temple University Press.

Schwartz, Jennifer and Bryan D. Rookey. 2008. "The Narrowing Gender Gap in Arrests: Assessing Competing Explanations Using Self-Report, Traffic Fatality, and Official Data on Drunk Driving, 1980-2004." Criminology 46(3):637-71.

$\rightarrow$ _ Darrell J. Steffensmeier, and Ben Feldmeyer. 2009. "Assessing Trends in Women's Violence Via Data Triangulation: Arrests, Convictions, Incarcerations, and Victim Reports." Social Problems 56(3):494-525. 
Shelden, Randall G. 2008. Crime and Criminal Justice in American Society. Long Grove, IL: Waveland Press.

Simon, Rita J. 1975. Women and Crime. Lexington, MA: D.C. Heath.

$\rightarrow$ Spelman, William. 2009. "Crime, Cash, and Limited Options: Explaining the Prison Boom." Criminology and Public Policy 8(1):29-77.

Spohn, Cassia. 1999. "Gender and Sentencing of Drug Offenders: Is Chivalry Dead?" Criminal Justice Policy Review 9:365-99.

- S. Welch, and John Gruhl. 1985. "Women Defendants in Court-The Interaction between Sex and Race in Convicting and Sentencing." Social Science Quarterly 66(1):178-85.

Steffensmeier, Darrell. 1980. "A Review and Assessment of Sex Differences in Adult Victims, 1965-77." Social Forces 58(4):1080-108.

_. 1993. "National Trends in Female Arrests, 1960-1990: Assessment and Recommendations for Research." Journal of Quantitative Criminology 9(4):413-41.

$\rightarrow-$ and Stephen Demuth. 2000. "Ethnicity and Sentencing Outcomes in U.S. Federal Courts: Who Is Punished More Harshly?" American Sociological Review 65(5):705-29.

$\rightarrow$ _ Jennifer Schwartz, Hua Zhong, and Jeff Ackerman. 2005. "An Assessment of Recent Trends in Girls' Violence Using Diverse Longitudinal Sources: Is the Gender Gap Closing?" Criminology 43(2):355-405.

Stemen, Don. 2007. "Impact of State Sentencing Policies on Incarceration Rates in the United States, 1975-2002." in New York, NY: Vera Institute of Justice [producer]: Inter-university Consortium for Political and Social Research. [published work by inter-university...]

—, Andres Rengifo, and James Wilson. 2006. "Of Fragmentation and Ferment: Impact of State Sentencing Policies on Incarceration Rates in the United States, 1975-2002," edited by U. S. Department of Justice. Washington, DC: National Institute of Justice.

Sutherland, Edwin H. 1947. Principles of Criminology, 4th edition. Chicago: University of Chicago Press.

Tonry, Michael. 1994. "Sentencing Reforms and Racial Disparities." Judicature 78(1):118-19, 159-60.

— 1995. "Twenty Years of Sentencing Reform: Steps Forward, Steps Backward." Judicature 78(1):169-72.

U.S. Bureau of the Census. 1965-69, 1971-79, 1981-89, 1991-99, 2001-08. "Bureau of the Census, Population Esitmates (On Line).". Washington, DC: Author.

U.S. Bureau of the Census. 1970, 1980, 1990, 2000. "Bureau of the Census, United States Census (Corresponding Year) on CD-ROM." Washington, DC: Author. [CITATION APPEARS ON PAGE 19].

—. 2006. "Bureau of the Census, Historical Poverty Tables, 2004 (On Line).". Washington, DC: Author.

U.S. Department of Justice. 1965-1983. "Bureau of Justice Statistics, Prisoners in State and Federal Institutions on December 31, 1965 (through 1983)." Washington, DC: Author. [CITATION APPEARS IN NOTE 2].

. 1965-2008. "Federal Bureau of Investigation, Uniform Crime Reporting Program Data, 1965 (through 2008)." Washington, DC: Author.

. 1984-1998. "Bureau of Justice Statistics, Correctional Populations in the United States, 1984 (throught 1998)." Washington, DC: Author.

- 1996. "Bureau of Justice Assistance, National Survey of Sate Sentencing Structures," edited by Bureau of Justice Assistance. Wahingtion, DC: Author.

. 1999-2008. "Bureau of Justice Statistics, Prisoners, 1999 (through 2008)." Washington, DC: Author. 
U.S. Department of Labor. 1965-2008. “Bureau of Labor Statistics, Geographic Profile of Employment and Unemployment, 1965 (through 2008)." Washington, DC: Author.

Visher, Christy A.1983. "Gender, Police Arrest Decisions, and Notions of Chivalry." Criminology 21(1):5-28.

Walker, Samuel, Cassia Spohn, and Miriam DeLone. 2004. The Color of Justice: Race, Ethnicity, and Crime in America. Belmont, CA: Wadsworth/Thomson Learning.

$\rightarrow$ Warr, Mark. 1995. "Public Opinion on Crime and Punishment." Public Opinion Quarterly 59(3):296-310.

$\rightarrow$ Western, Bruce. 2005. “Black-White Wage Inegualities, Employment Rates, and Incarcerceration." American Journal of Sociology 111(2):553-78.

Wooldridge, Jeffrey M. 1995. "Selection Corrections for Panel-Data Models under Conditional Mean Independence Assumptions." Journal of Econometrics 68(1):115-32.

- 2002. Econometric Analysis of Cross Section and Panel Data. Cambridge, MA: MIT Press.

Zhang, Yan, Christopher D. Maxwell, and Michael S. Vaughn. 2009. “The Impact of State Sentencing Policies on the US Prison Population." Journal of Criminal Justice 37(2):190-99.

Zimring, Frank E. 2001. “The New Politics of Criminal Justice." Pp. 145-49 in Mass Imprisonment in the USA, edited by D. Garland. London: Sage. 